\title{
Biochemical characterization and technofunctional properties of bioprocessed wheat bran protein isolates
}

\section{Arte, Elisa}

2019-08-15

Arte , E , Huang , X, Nordlund, E \& Katina , K 2019 , ' Biochemical characterization and technofunctional properties of bioprocessed wheat bran protein isolates ' , Food Chemistry , vol. 289 , pp. 103-111 . https://doi.org/10.1016/j.foodchem.2019.03.020

http://hdl.handle.net/10138/313103

https://doi.org/10.1016/j.foodchem.2019.03.020

cc_by_nc_nd

acceptedVersion

Downloaded from Helda, University of Helsinki institutional repository.

This is an electronic reprint of the original article.

This reprint may differ from the original in pagination and typographic detail.

Please cite the original version. 


\section{Accepted Manuscript}

Biochemical characterization and technofunctional properties of bioprocessed wheat bran protein isolates

Elisa Arte, Xin Huang, Emilia Nordlund, Kati Katina

PII:

S0308-8146(19)30473-X

DOI: https://doi.org/10.1016/j.foodchem.2019.03.020

Reference: FOCH 24453

To appear in:

Food Chemistry

Sciverse Sciencedirect

Received Date: $\quad 26$ November 2018

Revised Date: $\quad 7$ March 2019

Accepted Date: $\quad 7$ March 2019

Please cite this article as: Arte, E., Huang, X., Nordlund, E., Katina, K., Biochemical characterization and technofunctional properties of bioprocessed wheat bran protein isolates, Food Chemistry (2019), doi: https://doi.org/ 10.1016/j.foodchem.2019.03.020

This is a PDF file of an unedited manuscript that has been accepted for publication. As a service to our customers we are providing this early version of the manuscript. The manuscript will undergo copyediting, typesetting, and review of the resulting proof before it is published in its final form. Please note that during the production process errors may be discovered which could affect the content, and all legal disclaimers that apply to the journal pertain. 
Biochemical characterization and technofunctional properties of bioprocessed wheat bran protein isolates

Elisa ARTE ${ }^{a^{*}}$, Xin HUANGa ${ }^{\text {, Emilia NORDLUND }}{ }^{\mathrm{b}}$, Kati KATINA ${ }^{\mathrm{a}}$

a Department of Food and Nutrition, University of Helsinki, P.O. Box 66, FI-00014, Finland

b VTT Technical Research Centre of Finland Ltd., P.O. Box 1000, FI-02044 VTT, Espoo, Finland

*Corresponding author at: Department of Food and Nutrition, University of Helsinki, P.O. Box 66, FI-00014, Finland. Email address: elisa.arte@helsinki.fi,+358 503593776 (E.Arte) 


\section{Abstract}

The effect of three combinations of bioprocessing methods by lactic acid fermentation, cell wall hydrolyzing enzymes and phytase on the biochemical (protein, fat, carbohydrate composition) and technofunctional properties (protein solubility, emulsifying and foaming properties) of wheat bran protein isolates were evaluated. The bioprocessing increased the protein (up to $80 \%$ ) and fat content (up to $22.8 \%$ ) in the isolates due to the degradation of starch and soluble pentosans. Additional proteins, globulin $3 \mathrm{~A}$ and $3 \mathrm{C}$, chitinase, $\beta$-amylase and LMW glutenins, were identified from the electrophoretic pattern of the protein isolate bioprocessed with added enzymes. Generally, the bioprocessed protein isolate had lower protein solubility and stronger net charge in $\mathrm{pH}$ below 7 , when compared to the protein isolate made without bioprocessing. The emulsifying properties of the protein isolates were not affected by bioprocessing. However, the foaming stability of the protein isolates was nearly doubled by bioprocessing with cell wall hydrolyzing enzymes and phytase.

Keywords: Wheat bran, bioprocessing, protein isolate, technofunctional properties, emulsions, foaming 


\section{Introduction}

Raised awareness and discussion of health and environmental impacts of food production has increased the interest in new plant-based protein foods among consumers. To produce enough food for the growing global population with restricted arable land, the plant-based by-products of agro-food industry should be used more efficiently. Wheat bran and germ are the main by-product of flour milling. Depending on the milling technique and grade of flour obtained from the mill, $23-27 \%$ of the kernel weight is left out from food chain (Prückler et al., 2014). The bran is mainly used as feed and raw material in biofuel production and only in minor amounts as food (Prückler et al., 2014). Although, the main compound (approx. $50 \%$ ) of bran is dietary fiber, it contains a considerable amount of proteins as well (up to $18 \%$ ) and can be considered as a potential plant protein source (Coda, Rizzello, Curiel, Poutanen \& Katina, 2014; Prückler et al. 2014). The protein content in the individual bran layers are not evenly distributed and are prevalent in the aleurone layer $22.9 \mathrm{~g} / 100 \mathrm{~g}$ and in lesser extent in the outer $(5.1 \mathrm{~g} / 100 \mathrm{~g})$ and intermediate layers $(5.7 \mathrm{~g} / 100 \mathrm{~g})$ (Jensen \& Martens, 1983). Furthermore, the proteins in the outer layers and intermediate layers are mainly pathogen preventing enzymes and structural proteins strengthening the tissue (Jerkovic, Kriegel, Badner, Atwell \& Roberts, 2010). In the aleurone layer $66 \%$ of the proteins are composed of different types of globulins and contain less metabolic and defense enzymes (Jerkovic et al., 2010; Meziani, Nadaud, Gaillard-Martinie, Chambon, Benali \& Branlard, 2012). The storage proteins in bran are considered to be nutritionally superior to endosperm proteins due to higher content of essential and conditionally essential amino acids such as lysine, arginine, and glycine (Di Lena, Patroni \& Quaglia, 1997). Despite the good nutritional quality of bran proteins, the storage proteins in aleurone layer are surrounded by cell walls constructed of insoluble complex carbohydrates (mainly insoluble arabinoxylan and $\beta$-glucan) and lignin making the protein not fully digestible in the human 
gastrointestinal tract (Antoine et al., 2003). Furthermore, the phytic acid concentrated in the bran layer of wheat (up to $6 \%$ of the bran weight) forms complexes with the storage protein inside the cells and thus, also limiting the bran protein solubility and bioavailability (Fardet, 2010; Regvar et al., 2011).

Bioprocessing with lactic acid fermentation and enzymes is an effective tool to alter the dietary fiber and protein composition of cereal brans, and to enhance the bran overall nutritional quality (Coda et al., 2014; Nordlund, Katina, Aura \& Poutanen, 2013). In our previous work, treatment of wheat bran with carbohydrases and proteases increased the protein solubilization to $58 \%$ (Arte, Katina, Holopainen-Mantila \& Nordlund, 2016). Furthermore, activating the endogenous enzymes present in bran, the solubilization of proteins was increased up to $75 \%$ (Arte, Rizzello, Verni, Nordlund, Katina \& Coda, 2015). However, bioprocessing together with the hydrolytic enzymes and lactic acid fermentation was the most effective in increasing the digestibility of the bran proteins. The combined effect by enzymes and fermentation is based on the fact that the cell wall degrading enzymes increase the fermentable sugar and carbohydrate contents that improve the microbial growth of lactic acid bacteria and yeast (Coda et al., 2014). The better microbial growth causes faster acidification in the bioprocess that in turn activates the endogenous enzymes in bran. The faster activation of endogenous enzymes enhances the hydrolysis and solubilization of proteins resulting in improvement of protein digestibility as well.

Despite improving the nutritional quality of bioprocessed wheat bran proteins, the physicochemical properties of proteins determine the usefulness in food applications. Protein isolates have been widely studied and produced from bran proteins such as oat and rice, however, from wheat bran proteins, in particularly bioprocessed wheat bran proteins, the functional properties have not been fully characterized. Further, only few studies have been made of applying lactic acid fermentation in the process of producing isolated protein 
from plant material. In recent studies by Meinlschmidt, Ueberham, Lehman, SchweiggertWeisz and Eisner (2016) and Klupsaite, Juodeikiene, Zadeike, Bartkiene, Maknickiene and Liutkute (2017) lactic acid fermentation was used to increase the protein solubility in soy protein isolate and lupine protein isolate, respectively. The lactic acid fermentation of soy protein isolate doubled the foaming activity but reduced the emulsifying capacity by $50 \%$ (Meinlschmidt et al., 2016). However, the lactic acid fermentation of lupine proteins improved significantly both, the emulsifying and foaming capacities (Klupsaite et al., 2017). Both studies concluded that the hydrolysis of proteins during lactic acid fermentation decreased the protein molecular weight to smaller protein and oligopeptides. These modifications during fermentation modified the structural conformations of the proteins to more loose and flexible that strengthened the air-water-interface and stabilising the foam structure.

In this work, the effect of three combinations of bioprocessing methods by lactic acid bacteria, cell wall degrading enzymes and phytase on the wheat bran protein characteristics and technological properties was evaluated. The effect of bioprocessing on the protein, fat and carbohydrate composition of the isolated protein fraction was studied. Also, the changes in the protein profile were determined by analyzing the amino acid composition, electrophoretic pattern and secondary structure of the isolated protein. Six of the most interesting protein bands from the SDS-PAGE gels were identified with mass spectrometry. The technological features, protein solubility, net charge and surface hydrophobicity as well as emulsifying and foaming properties were studied from the bioprocessed wheat bran proteins.

\section{Materials and methods}

2.1 Raw materials, starters and enzymes 
Commercial, milled wheat bran was kindly provided by Lantmännen Cerealia AB (Malmö, Sweden). Over $90 \%$ of the bran particles were smaller than $378 \mu \mathrm{m}$. The bran contained $54 \%$ total dietary fiber, $14 \%$ protein, $11 \%$ carbohydrates $(2.1 \%$ sugars $)$, and $6 \%$ fat and ( $1.1 \%$ saturated fat). For bioprocessing of bran, commercial starter culture was used for that contained lactic acid bacteria $L b$. brevis and $L b$. plantarum, and yeast $S$. cerevisiae (Florapan 4K, Lallemand, Montreal, Canada). The enzymes used were Bel'ase B210 (Puratos, Brussels, Belgium), Viscoferm (Novozymes, Bagsværd, Denmark) and Phytase (Ultra-Biologics Inc., Quebec, Canada). Bel'ase B210 had xylanase activity of 19517 nkat/g $(\mathrm{pH} 5)$ and $\beta$-glucanase activity of 804 nkat/g (pH 6.5) analyzed as in Bailey, Biely and Poutanen (1992) and Zurbriggen, Bailey, Penttilä, Poutanen and Linko (1990), respectively. Viscoferm had xylanase activity of $33284 \mathrm{nkat} / \mathrm{ml}$ and $\beta$-glucanase of $44317 \mathrm{nkat} / \mathrm{ml}$. Viscoferm had also side activities of acidic protease $2.5 \mathrm{nkat} / \mathrm{ml}(\mathrm{pH} \mathrm{5.5)}$, cellulase 13036 nkat/ml (FPU, pH 5.5) and endoglucanase 149 nkat/ml (pH 5.0) (Arte et al., 2016). Phytase had a phytase activity of $25005 \mathrm{nkat} / \mathrm{g}$ according to the manufacturer.

2.2 Bioprocessing of wheat bran and extraction and isolation of the proteins Three different wheat bran bioprocesses were made: 1) bioprocessing with starters Florapan 4K (Str), 2) with starters and cell wall hydrolyzing enzymes Bel'ase B210 and Viscoferm (StrE), 3) and starters, Bel'ase B210, Viscoferm and phytase (StrEP). The starter was added in ratio of 1:1000 to wheat bran, the enzymes Bel'ase B210 and Viscoferm were added according to their xylanase activity of 500 nkat/g bran, and phytase 250 nkat/g bran. The bioprocessing conditions $8 \mathrm{~h}, 35^{\circ} \mathrm{C}$ (bran-water ratio of $30: 70 \mathrm{w} / \mathrm{v}$ ) and the enzyme dosages were chosen by mathematical modelling in a pre-study in order to obtain maximal protein solubilization without extensive protein hydrolysis (data not shown). At the end of the bioprocesses, the $\mathrm{pHs}$ of the bran-water-slurries were $5.6 \pm 0.3$. The bran proteins were extracted overnight $\left(4^{\circ} \mathrm{C}\right.$ ) with $300 \mathrm{mM} \mathrm{NaOH}$ (ratio of 1:4 bran and $\mathrm{NaOH}, \mathrm{pH} 11.5 \pm 0.2$ ) 
and the solubilized proteins centrifuged $\left(20 \mathrm{~min}, 15500 \mathrm{~g}, 21^{\circ} \mathrm{C}\right)$. For comparison, a control wheat bran protein (Control) was made by extracting the proteins from native bran with $\mathrm{NaOH}$. The solubilized proteins in the supernatant were precipitated by adjusting the $\mathrm{pH}$ to 5.5 with $2 \mathrm{M} \mathrm{HCl}$. The precipitated proteins were centrifuged as previously and collected for dialysis against water (Dialysis tubing cellulose membrane, cut-off $14000 \mathrm{~g} / \mathrm{mol}$, SigmaAldrich, Darmstadt, Germany) to remove the hydrolysis products (i.e. free sugars and amino acids) formed during bioprocessing and salt formed during protein precipitation. The dialysis was performed in $4^{\circ} \mathrm{C}$ and the water replaced at least three times every 8 hours. Finally, the isolated proteins were lyophilized and used as a starting material in the study.

\subsection{Chemical analysis of the protein isolates}

The moisture content of the protein isolates was determined by the American Association of Cereal Chemists (AACC) method no. 44-15A (AACC, 2003). The protein content of the bran protein isolates was analyzed by the Dumas combustion method, AACC method no. 46-30, with a conversion factor of 6.31 from nitrogen to protein (AACC International, 2003; FAO, 2003). The peptide content of the protein isolates was determined by the o-phtaldialdehyde method (Church, Swaisgood, Porter \& Carignani, 1983). The carbohydrate composition was determined by the contents of soluble pentosans, total starch and free sugars. The contents of soluble pentosans and total starch in the isolates were analyzed as in Santala, Lehtinen, Nordlund, Suortti and Poutanen (2011) and by AACC method no. 76-13 (AACC, 2003), respectively. The free sugar content was determined as the combined amounts of glucose, saccharose, fructose and maltose analyzed by high performance anion exchange chromatography with pulsed amperometric detection (HPAEC-PAD). The protein isolates in $\mathrm{mQ}$-water (1\%) were filtered through Amicon Ultra-0.5 centrifugal filter units (Millipore, Billerica, USA) by centrifuging (10 min, $12210 \mathrm{~g})$. The samples $(10 \mu \mathrm{l})$ were injected to the HPAEC-PAD system with a CarboPac PA1 column $(250 \times 4 \mathrm{~mm}$, Dionex, Sunnyvale, CA) 
as in Xu et al. (2017). The fat in the protein isolates was extracted by a mixture of heptane and isopropanol (3:2, v/v) and analyzed by the gravimetric method using Soxtec Avanti 2050 system with Soxtec Auto Control Unit (Foss, Hillerød, Denmark), where the boiling time was $45 \mathrm{~min}\left(170^{\circ} \mathrm{C}\right)$, washing time $30 \mathrm{~min}$ and collection time $10 \mathrm{~min}$. The fat content was calculated as fresh weight (\%) in the protein isolate. The protein, carbohydrate and fat contents were analyzed in duplicate.

For determing the amino acid profile, the protein isolates were either alkaline hydrolyzed (tryptophan) or acid hydrolyzed (rest of the amino acids). To analyze the tryptophan content, $33 \mathrm{mg}$ of the protein isolates were hydrolyzed for $24 \mathrm{~h}\left(110^{\circ} \mathrm{C}\right)$ with $4 \mathrm{ml}$ alkaline hydrolyzing solution (4 $\mathrm{M} \mathrm{NaOH}, 1 \mathrm{mM}$ Norvaline as internal standard). The samples were then centrifuged for $10 \mathrm{~min}(12210 \mathrm{~g})$ and an aliquot of supernatant was neutralized with $0.5 \mathrm{M}$ $\mathrm{HCl}$. To analyze the cysteine and methionine contents, the protein isolates $(33 \mathrm{mg})$ were pre-oxidized for $16 \mathrm{~h}\left(4^{\circ} \mathrm{C}\right)$ by $1.5 \mathrm{ml}$ of solution containing $78.1 \%(\mathrm{v} / \mathrm{v})$ acetic acid, $10 \%(\mathrm{v} / \mathrm{v})$ $\mathrm{H}_{2} \mathrm{O}_{2}(30 \%)$ and $5 \mathrm{mM}$ of phenol. The oxidizing reaction was stopped by adding $252 \mathrm{mg}$ of sodium bisulphite. The samples were then hydrolyzed for $24 \mathrm{~h}\left(110^{\circ} \mathrm{C}\right)$ with $6 \mathrm{ml}$ of acid solution (6 M HCl, $2 \mathrm{mM}$ Norvaline and $0.1 \%$ phenol), centrifuged (10 min, $12210 \mathrm{~g}$ ) and neutralized with $\mathrm{NaOH}(2 \mathrm{M})$. To determine the contents of the rest of amino acids, the protein isolates were hydrolyzed as above without pre-oxidation. The isolates $(33 \mathrm{mg})$ were hydrolyzed with $5 \mathrm{ml}$ of the acid solution, centrifuged as before and neutralized with $\mathrm{NaOH}$ (2 M). Finally, the samples were diluted (1:4 v/v) to AccQ Tag Ultra Borate buffer. The protein isolate samples $(10 \mu \mathrm{l})$ were derivatised adding $70 \mu \mathrm{l}$ borate buffer and $20 \mu \mathrm{l}$ Waters AccQ A2 reagent (Waters AccQ Tag Ultra Reagent, Milford, USA), and incubated 1 min in room temperature followed by $10 \mathrm{~min}$ at $55^{\circ} \mathrm{C}$. The derivatised sample $(1 \mu \mathrm{l})$ was injected in the ultra-high performance liquid chromatography UHPLC system with a Waters Acquity HSS T3 column $(2.1 \times 100 \mathrm{~mm}$, particle size $1.8 \mu \mathrm{m})$ described in detail by Bao, Boeren and 
Ertbjerg (2018). The peaks were identified by the retention times and quantified by the area of the peak. The amino acid content of the protein isolates was calculated as $\mathrm{g} / 100 \mathrm{~g}$ of protein. The analysis were made in triplicate.

\subsection{Biochemical characterization}

The electrophoretic pattern of the protein isolates was analyzed by SDS-PAGE (Laemmli, 1970). The protein isolates $(5 \mathrm{mg})$ were first defatted with $500 \mathrm{ml}$ acetone to avoid smearing of the protein bands. The acetone was removed by centrifugation ( 5 min, $12210 \mathrm{~g}$ ) and evaporation for overnight in fume hood. The proteins were then extracted to $1 \mathrm{ml}$ tris- $\mathrm{HCl}$

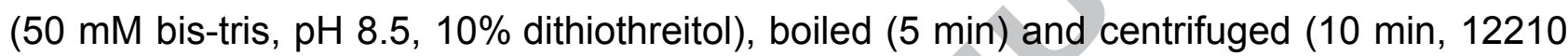
g). The samples were pipetted to Bis Tris $10 \%$ mini gels according to the protein content (35 $\mu \mathrm{g} /$ protein in well). Seeblue Plus2 Pre-Stained protein standard (3-198 mol/g, LC5925, Invitrogen, Walthman, MA) was used as a protein standard. The gels were run for $40 \mathrm{~min}$ (200 V, 100-120 mA), stained overnight by Coomassie blue-TCA solution and washed with mQ-water until clear gels were obtained.

From the SDS-PAGE gel of StrEP, six of the most interesting protein bands (approx. MW of $90000,56000,51000,37000,26000$ and $24000 \mathrm{~g} / \mathrm{mol}$ ) were identified by mass spectrometry and proteome data analysis as in Turunen et al. (2012) with minor modifications. The MALDI-TOF/TOF analyses were performed with UltraFlextreme (Bruker Daltonics, Bremen, Germany) with SmartBeam ${ }^{\mathrm{TM}}$ laser $(355 \mathrm{~mm})$. The mass spectra was collected from 10000 laser shots and up to 20000 MS/MS spectra. 'Other green plants' was chosen for taxonomy field (6423380 sequences) using Matrix Science's Mascot (Matrix Science Ltd, UK).

The secondary structure of the protein isolates were analyzed with Fourier Transform Infrared spectrophotometry with attenuated total reflection sampling accessory attached (ATR-FTIR, Perkin Elmer Instruments, Spectrum One FT-IR spectrophotometer, Krakow, Poland). The protein isolate sample was placed on top of the diamond crystal, pressed with 
a force gauge 65 and the spectra were collected in the 4000 to $800 \mathrm{~cm}^{-1}$ infrared spectral range at room temperature. Each spectrum was an average of 10 scans at $4 \mathrm{~cm}^{-1}$ resolution. At least five spectra were collected from each sample. After the baseline correction, Fourier self-deconvolution and second derivative spectra were employed for band narrowing and peak fitting was achieved with Peakfit (version 4, Systat Software Inc., USA). The secondary structure of the proteins were identified from the amide I band with a spectral range $1700-$ $1600 \mathrm{~cm}^{-1}$. The proportions of the secondary structures were calculated as in Bunaciu, Fleschin and Aboul-Enein (2014): the $\beta$-sheet, random, $\alpha$-helix and $\beta$-turns were estimated from the relative band areas of $1640-1620 \mathrm{~cm}^{-1}$ and $1695-1690 \mathrm{~cm}^{-1}, 1648-1640 \mathrm{~cm}^{-1}$, $1656-1658 \mathrm{~cm}^{-1}$ and $1666-1695 \mathrm{~cm}^{-1}$, respectively.

The surface hydrophobicity of the proteins of the isolates was determined by the 1-anilino8-napthalenesulfonat (ANS) binding method as in Wang et al. (1999) with minor modifications. The protein isolates suspended in $50 \mathrm{mM}$ potassium phosphate buffer $(\mathrm{pH}$ 7.4) were diluted to obtain protein concentrations $0.15 \%$ to $0.0015 \%$, measured by DC Protein assay kit (Bio-Rad, Hercules, CA, USA) and quantified using bovine serum albumin (Merck KGaA, Darmstadt, Germany) as a protein standard. The diluted protein solution (1 $\mathrm{ml}$ ) was mixed with $5 \mu \mathrm{l}$ of $8 \mathrm{mM}$ ANS in $50 \mathrm{mM}$ potassium phosphate buffer in a microplate and the fluorescence intensity $(\mathrm{FI})$ of the ANS-protein samples were measured with a spectrofluorometry (Tecan Infinite M200, Männedorf, Switzerland). The measurement was performed using excitation wavelength and bandwidth of $390 \mathrm{~nm}$ and $9 \mathrm{~nm}$, respectively, and emission wavelength and bandwidth of $470 \mathrm{~nm}$ and $20 \mathrm{~nm}$, respectively. The initial slope $\left(\mathrm{S}_{0}\right)$ of the $\mathrm{FI}$ versus the protein concentration was calculated by linear regression analysis and represented as protein surface hydrophobicity. At least four replicates were performed from the protein isolates.

\subsection{Technofunctional properties}


The protein solubility according to $\mathrm{pH}$ was analyzed by dissolving the lyophilized isolates in to four buffer solutions in the $\mathrm{pH}$ range of 4 to 8 . The protein isolates were dissolved $(2 \mathrm{~h}$, room temperature) into citric acid buffer ( $\mathrm{pH} 4$ and 5) or sodium phosphate buffer ( $\mathrm{pH} 6,7$ and 8 ) in a concentration of $10 \mathrm{mg} / \mathrm{ml}$, after which the samples were centrifuged for $20 \mathrm{~min}$ $(3220 \mathrm{~g})$. The protein content in the supernatants was analyzed by Dumas combustion method and expressed as the percentage of the solubilized protein from the total protein content in bran. The net charge ( $\zeta$-potential) of the proteins in the solutions were also determined from the same set of samples by Zetasizer nano series (Nano 2S, Malvern Instruments, Malvern, UK) using folded capillary cuvettes (DTS 1060, Malvern Instruments). The $\zeta$-potential was calculated from the electrophoretic mobility using refractive index 1.45 and Smoluchnowski approximation. The samples were analyzed in triplicate.

The emulsifying properties of the bran protein isolates were evaluated. The protein isolates dissolved in $50 \mathrm{mM}$ sodium phosphate buffer $(0.2 \% \mathrm{w} / \mathrm{v}, \mathrm{pH} 7.4)$ were pre-homogenized with 5\% rapeseed oil (Apetit, Avena Kantvik Oy, Finland) by Ultra-turrax T25 (1 min, 13600 rpm, IKA-laboratortechnik, Staufen, Germany). The emulsions were immediately further homogenized for 5 min with 700 bar by Microfluidiziser Y-110 (Microfluidics, Newton, MA). The particle sizes of the oil-droplets in the emulsions were analyzed with laser diffraction particle size analyzer (Mastersizer 3000 Hydro, Malvern Instruments Ltd., Worcestershire, UK) with a wet sampling system (stirrer speed $2500 \mathrm{rpm}$ ). For the calculation of particle size, scattering model Mie was used with particle size refractive index 1.47 and absorption index 0 . Data on volume mean diameter $D[4,3]$ and median droplet size $D(50)$ were collected from the emulsion samples. The microstructure of the emulsions were also examined immediately after preparation with light microscopy Zeiss Axio Lab A1 with attached Axio camera. Pictures were taken at $100 \times$ magnification. The analysis were made in triplicate. 
The foaming properties of the isolates were evaluated by using Dynamic Foam Analyzer DFA100 (Krüss $\mathrm{GmbH}$, Hamburg, Germany). In the system, $100 \mathrm{ml}$ of air $(0.3 \mathrm{l} / \mathrm{min}$, stopped approx. after 28 s of foaming) was conducted through a paper filter (FL 4520, pore size 12$16 \mu \mathrm{m}$, Krüss $\mathrm{GmbH}$, Hamburg, Germany) to $25 \mathrm{ml}$ of protein solution $(0.2 \% \mathrm{w} / \mathrm{v}$ in potassium phosphate buffer, $\mathrm{pH}$ 7.4). The total foam height (liquid + foam) was measured by light transmission through the column and followed for $30 \mathrm{~min}$. The following time was started from the point, where all the air was conducted to the solution. Evolution of bubble count was recorded at the same time for 30 min by the Foam Structure Module (FSM), which was attached to the Dynamic Foam Analyzer at a height of $55 \mathrm{~mm}$ to the column. In addition, images of the foam structure was chosen to be taken every $5 \mathrm{~min}$ of the $30 \mathrm{~min}$ following time. The measurements were made in triplicate.

\subsection{Statistical analyses}

The results were calculated as means of two (chemical composition of protein isolates) or at least from triplicate analysis results. The data was analyzed by one-way ANOVA; paircomparison of the analysis means was obtained by Tukey's procedure $(p>0.05)$ using the statistical software IBM SPSS Statistics 22. When the response differed significantly $(p<0.05)$, it was indicated with a different letter.

\section{Results}

3.1 Characterization of bioprocessed wheat bran protein isolates

The changes in the chemical composition of the wheat bran protein isolates are presented in Table 1. The bioprocessing clearly influenced the chemical composition of the protein isolates. The protein content increased significantly from $67.0 \%$ (Control) to $81.0 \%$ (Str), $81.7 \%$ (StrE) and $79.9 \%$ (StrEP). The bioprocessing with Str also increased significantly the peptide content from $62.2 \mathrm{mg} / \mathrm{g}$ isolate (Control) to $75.8 \mathrm{mg} / \mathrm{g}$ of isolate in the isolate 
prepared with fermentation (Str). When the enzymes were involved in the bioprocess (StrE and StrEP), the peptide content was similar to Control. The fat content was increased by bioprocessing, being highest in the isolate bioprocessed with cell wall degrading enzymes and phytase (22.8\%). The bioprocessing caused a significant decrease of carbohydrates in the protein isolates. This was most evident in the content of total starch, which decreased significantly from $13.4 \%$ (Control) to $2.0 \%, 1.1 \%$ and $0.5 \%$ in Str, StrE and StrEP, respectively. Also, the content of soluble pentosans decreased significantly from $2.5 \%$ (Control) to $1.3 \%, 1.1 \%$ and $1.5 \%$ in Str, StrE, and StrEP, respectively. A small amount of free sugars was observed in the isolates that was increased from $0.44 \%$ (Control) to $0.7 \%$ by bioprocessing.

Glu, Pro, Arg and Leu were the most abundant amino acids in the isolates (Table 2). Overall, minor changes were observed in the amino acid profiles of the protein isolates. The content of Pro was significantly decreased in all bioprocessed isolates $(8.34 \mathrm{~g} / 100 \mathrm{~g}$ in Str, 7.53 $\mathrm{g} / 100 \mathrm{~g}$ in StrE, and $7.68 \mathrm{~g} / 100 \mathrm{~g}$ of protein in StrEP), compared to the Control (8.86 $\mathrm{g} / 100$ $\mathrm{g}$ of protein). Bioprocessing with the addition of cell wall degrading enzymes (StrE) increased significantly the contents of Cys and Trp from 0.44 (Control) to $0.58 \mathrm{~g} / 100 \mathrm{~g}$ of protein and from 4.75 (Control) to $6.59 \mathrm{~g} / 100 \mathrm{~g}$ of protein, respectively. Bioprocessing with the addition of both cell wall degrading enzymes and phytase increased significantly the contents of Thr and Val, from 3.16 (Control) to $3.41 \mathrm{~g} / 100 \mathrm{~g}$ protein and 4.50 (Control) to $4.76 \mathrm{~g} / 100 \mathrm{~g}$ protein, respectively.

The bioprocessing of wheat bran caused changes in the proportions of $\beta$-sheet and $\beta$-turn secondary structures of the proteins in the isolates. In all of the protein isolates, the $\beta$-turn structure was the most abundant protein secondary structure (Table 2). The bioprocessing caused a significant increase in the proportion of $\beta$-sheet structure from $22.0 \%$ (Control) to $31.4 \%$ (Str), $35.1 \%$ (StrE) and $28.0 \%$ (StrEP). The proportion of $\beta$-turns was $59.7 \%$ in 
Control isolate and decreased to $49.1 \%$ in Str, $46.5 \%$ in StrE and $55.8 \%$ in StrEP. The proportions of random coil and a-helix were not influenced by the bioprocessing methods, being $5.7-8.3 \%$ and $10.5-12.5 \%$, respectively, in all of the isolates.

The protein electrophoretic pattern in the isolates was profiled with SDS-PAGE and selected protein bands were identified with mass spectrometry. In all of the protein isolates, proteins bands were visible throughout the wells from MW 97000 to $14000 \mathrm{~g} / \mathrm{mol}$ (Figure 1). Proteins with a MW of 51000 and $38000 \mathrm{~g} / \mathrm{mol}$ were most intensively stained proteins and major proteins in these bands were identified as globulin 3A and 3C (I6QQ39 and B7U6L3, respectively). Additional bands with a MW approximately 60000, 45000, 26000 and 24000 $\mathrm{g} / \mathrm{mol}$ were observed especially in the isolates StrE and StrEP. Major proteins in these bands were identified as $\beta$-amylase (P93594), chitinase (Q8W427) and low-molecular-weight glutenin (LMW, P10386). Also, the protein band with MW of $90000 \mathrm{~g} / \mathrm{mol}$ was identified as chitinase and globulin $3 \mathrm{~A}$ and $3 \mathrm{C}$.

\subsection{Technofunctional properties of wheat bran protein isolates}

The protein solubility and $\zeta$-potential in $\mathrm{pH}$ range of 4 to 8 was analyzed from the aqueous solutions of protein isolates. As expected, the protein solubility was increased with $\mathrm{pH}$ increasing from acidic towards alkaline. Altogether, the bioprocessed protein isolates had lower protein solubility in $\mathrm{pH} 4$ to 7 , when compared to the Control (Figure 2A). In the Control, the protein solubility increased with increasing $\mathrm{pH}$, having lowest solubility in $\mathrm{pH} 4(24.7 \%)$ and increasing significantly in $\mathrm{pH}$ above 5 . Also, the $\zeta$-potential of the Control was close to zero $(-1 \mathrm{mV})$ at $\mathrm{pH} 5$, and had stronger negative charge below and above this $\mathrm{pH}$ (Figure 2B). The protein solubility was lower than the Control and uniform within the bioprocessed protein isolates in the $\mathrm{pH}$ range 4 to 6 , being $21.5-23.0 \%$, and showing lowest solubility in Str at pH $5(21.5 \%)$ and in StrE and StrEP at pH 6 (21.6\% and 22.1\%, respectively). When 
the $\mathrm{pH}$ increased from 6 to 7 and further to 8, the protein solubility increased significantly, being highest in StrEP at $\mathrm{pH} 8(36 \%)$. The $\zeta$-potential pattern of Str was similar to Control, having lowest net charge $(-0.5 \mathrm{mV})$ at $\mathrm{pH} 4$ and significantly increasing negative net charge with increasing $\mathrm{pH}(-10 \mathrm{mV}$ at $\mathrm{pH}$ 8). In the StrE and StrEP, the net charge of the proteins was positive (+2.6 and $+2.7 \mathrm{mV}$, respectively) in $\mathrm{pH} 4$ and changed to strong negative charge at $\mathrm{pH} 5(-13.6 \mathrm{mV}$ and $-11.5 \mathrm{mV})$. In the $\mathrm{pH}$ range 5 to 8 , the net charge remained somewhat constant and ranged between -9.3 and $-14.2 \mathrm{mV}$ in StrE and StrEP, respectively. The surface hydrophobicity $\left(\mathrm{S}_{0}\right)$ of the proteins in the isolates was significantly lower, when compared to BSA $(400000 \pm 0)$ However, when compared to the Control, the protein surface hydrophobicity increased significantly $(p<0.05)$ from $103310 \pm 3252$ to $121143 \pm 5009$ and $131861 \pm 5505$ in Str and StrE, respectively. The surface hydrophobicity of StrEP was noticed to increase to $110685 \pm 6214$ however, the increase was not statistically significant when compared to the Control $(p>0.05)$.

The bioprocessed bran protein isolate increased the particle size distribution in oil-in-water emulsions, however, all the protein isolates were unstable (Figure 3). The emulsion made with Control protein isolate had the smallest volume mean diameter (D[4,3] $6.0 \pm 0.1 \mu \mathrm{m})$ and median droplet diameter D50 of $4.6 \pm 0.1 \mu \mathrm{m}$ (Table 3). Compared to the Control isolate containing emulsion, all the emulsions produced with the bioprocessed protein isolates had significantly larger mean volume diameter and median droplet diameter $(p<0.05)$. The Str, StrE and StrEP had mean volume diameter $\mathrm{D}[4,3]$ of $7.3 \pm 0.0 \mu \mathrm{m}, 7.4 \pm 0.0 \mu \mathrm{m}$ and $7.0 \pm$ $0.0 \mu \mathrm{m}$, respectively. In addition, the median droplet diameter, D50, of the emulsions containing bioprocessed protein isolates was significantly increased $(p<0.05)$ to $6.6 \pm 0.0$ $\mu \mathrm{m}, 6.7 \pm 0.0 \mu \mathrm{m}$ and $6.3 \pm 0.0 \mu \mathrm{m}$ in Str, StrE and StrEP, respectively.

The foam height was not effected by bioprocessing but foam stability was improved significantly by bioprocessing, when compared to Control (Figure 4A). The impact of 
bioprocessing in the foam stability was observed as the differences in the curve shapes of the decay phase in total foam height as well as the differences in the foam bubble structure. The Control protein decayed drastically during first $15 \mathrm{~min}$ from $104 \mathrm{~mm}$ to $40 \mathrm{~mm}$, after which the decay slowed down and decreased to $30 \mathrm{~mm}$ during the next $15 \mathrm{~min}$. The initial bubble count for the Control protein foam increased during the air conduction (first $1 \mathrm{~min}$ ), after which the bubble count decreased to approx. 3 bubbles $/ \mathrm{mm}^{2}$ during $3 \mathrm{~min}$ time. After $5 \mathrm{~min}$ from foam formation, the bubble count varied between 4.5 to 9 bubbles $/ \mathrm{mm}^{2}$. The images of the Control foam showed the degradation of foam structure by coalescence the bubbles (Figure 5). The bubble count and images were not detectable after $15 \mathrm{~min}$, due to the decrease of foam height under the observation height $(55 \mathrm{~mm})$ of the Foam Structure Module. The bubble count half life time ( $\mathrm{t}_{\mathrm{BC} 1 / 2}$ : time, in which the bubble count is reduced to $50 \%$ from the initial value) supported the observations obtained from the bubble count and bubble images, being $76 \pm 6 \mathrm{~s}$. in the Control foam. The foams made with bioprocessed protein were more stable, decreasing more linearly from $104 \mathrm{~mm}$ to $60-65 \mathrm{~mm}$ during the first $15 \mathrm{~min}$ and to $40 \mathrm{~mm}$ during the next $15 \mathrm{~min}$. The bioprocessed protein foams, especially StrEP, were noticed to form more stable bubble structures having less variation in bubble count during observation time (Figure 4B). The highest bubble count was obtained with StrE, in which the bubble count decreased to approximately $3-5$ bubbles $/ \mathrm{mm}^{2}$ during the first 5 min and was stable for the next $10 \mathrm{~min}$. Also, the images of the foam structure showed that even coalescence of bubbles occurred, the foam structure was less decayed during the 30 min observation time. Again, these observations were supported by the bubble count half life time, which was significantly increased in Str, being $93 \pm 5 \mathrm{~s}$ and nearly doubled (when compared to Control) in StrE and StrEP to $132 \pm 3 \mathrm{~s}$ and $133 \pm 0 \mathrm{~s}$, respectively.

\section{Discussion}




\subsection{Biochemical characteristics of the wheat bran protein isolates}

The bioprocessing clearly increased the protein content of the isolates, with simultaneous decrease of carbohydrates. The significant degradation of total starch and soluble pentosans by the fermentation treatment was presumably due to the activation of an array of endogenous enzymes such as amylases and xylanases (Gänzle, 2014). The addition of cell wall degrading enzymes intensified the hydrolysis of starch and soluble pentosans into simple sugars, which were then removed from isolates during the dialysis resulting in even lower content of total carbohydrates. The results are consistent with our previous work, where wheat bran treated for $6 \mathrm{~h}$ with cell wall hydrolyzing enzyme preparations Depol 761P (xylanase) or Viscoferm released the attached endosperm remains from the aleurone layer (Arte et al., 2016). During the bioprocessing, the $\mathrm{pH}$ of the bran-water slurry decreased from 6.7 to $5.6 \pm 0.3$. The acidification during sourdough fermentation by the lactic acid bacteria is known to activate also several endogenous proteases in wheat grain, such as aspartic proteases and carboxypeptidases (Gänzle, 2014). The primary proteolysis of hydrolyzing protein into peptides during lactic acid fermentation is due by the endogenous cereal proteases followed by the secondary proteolysis caused by lactobacilli, hydrolyzing the peptides into amino acids (Gänzle \& Gobbetti, 2013). In this study, the protein content in the isolates was increased approximately $20 \%$ by all bioprocess methods. In addition, the content of peptides were increased from $62.2 \mathrm{mg} / \mathrm{g}$ (Control) to $75.8 \mathrm{mg} / \mathrm{g}$ with bioprocessing with starters, indicating hydrolysis and liberation of peptides from the bran matrix. However, when the cell wall hydrolyzing enzymes were involved, the peptide content were similar to Control. The reason for the lower content of peptides in StrE and StrEP is not clear, but it may be related to the small protease side activity in the Viscoferm preparation. The peptides formed during lactic acid fermentation may have been hydrolyzed into amino acids by the small protease activity and were then removed from isolates during the dialysis. 
The fat content increased in the protein isolates with the bioprocessing methods, likely by the decrease of total carbohydrates that increased the proportions of both fat and protein in the isolates. Interestingly, the addition of both cell wall degrading enzymes and phytase had the most significant effect in decreasing total starch and in increasing the fat content. Majority of the phytic acid in wheat kernel is located together with the protein inside protein storage vacuoles surrounded by oleosomes (Regvar et al., 2011). Also, phytic acid has been reported to be found in the germ fraction as well (Bilgiçli \& İbanoğlu, 2007). The addition of both cell wall hydrolyzing enzymes together with phytase might have been more effective in degrading the complex cell wall structure of aleurone layer liberating the proteins and lipids in the cells.

The results obtained in this study are in alignment with Wang et al. (1999) where enzymatic treatment with xylanase and phytase increased the protein content of defatted rice bran protein isolate from $74.5 \%$ (without enzyme addition) to $92.0 \%$. They concluded that the simultaneous effect of these enzymes most probably liberated more protein bound to cellular compounds and/or to phytate. In contrast to this study, the used rice bran was defatted and the bran protein isolate was made without dialysing of the precipitated protein. The removal of fat and presence of small proteins, peptides and free amino acids were most probably the cause of the high total protein content obtained in the study by Wang et al. (1999). In our pre-experiments of producing wheat bran protein isolates, defatting of wheat bran was also performed by hexane/methanol solution (1:1) prior to bioprocessing with only starters. The defatting increased the total protein content of the isolate up to $97 \%$ (data not shown). However, in the actual study set up, defatting was chosen not to be done to avoid additional processing steps during the isolation of proteins.

The bioprocessing had an effect on the endosperm proteins still attached to the aleurone layer of bran. The decreased content of proline and $\beta$-turn structure indicated the hydrolysis 
of endosperm proteins, as the gliadins and high-molecular-weight subunits of glutenins are rich in $\beta$-turns due to the proline-rich repetitive domain (Shewry \& Tatham, 1990). Decreasing content of amino acids relevant to prolamins has been reported also in a study, where a solid-state fermentation of wheat bran was performed for 7 days with mycelia fungi (Di Lena et al., 1997). Additional bands with a molecular weight of $24000 \mathrm{~g} / \mathrm{mol}$ were observed from the SDS-PAGE gels that were identified as LMW glutenins. The bioprocessing likely caused the partial hydrolysis of LMW glutenins, which were then solubilized and present in the protein isolates. Also, in previous studies the microscopic images of bioprocessed wheat and rye bran has shown hydrolysis of protein from the endosperm still attached to the aleurone layer (Arte et al., 2016; Nordlund et al., 2013). As said, the cell walls in the aleurone layer and the endosperm are thinner, containing less substituted arabinoxylans that are more prone to hydrolysis with both added cell wall hydrolyzing enzymes and endogenous enzymes activated by the lactic acid fermentation (Katina et al., 2012).

The bioprocessing was shown to liberate and solubilize the proteins from bran aleurone cells as well. The bioprocessing with enzymes increased significantly the content of Thr, Trp and Val that are known to be in higher amounts in bran than of endosperm (Khan et al., 2009). Also, the hydrolysis of residual gliadins and glutelins and the liberation of proteins from the bran matrix caused the increase in proportion of $\beta$-sheet structures. Majority of the wheat aleurone proteins are different types of globulins that are rich in $\beta$-sheet structures (Meziani et al., 2012; Marcone, Kakuda \& Yada, 1998). In native proteins, the $\beta$-sheet structures as well as the hydrophobic groups have a tendency of being buried in the core, whereas polar residues and helical structures are prevalent in the surface of the protein (Marcone et al., 1998; Damodaran, 2008). In general, the surface hydrophobicity of the protein isolates was low, when compared to bovine serum albumin. However, the modest hydrolysis of proteins 
during bioprocessing might have caused unfolding of the protein revealing the buried hydrophobic structures on the surface, thus increasing the surface hydrophobicity. Similar findings have been reported by Jung, Murphy and Johnson (2005), where partial hydrolysis of soy protein isolate by commercial proteolytic enzymes increased the surface hydrophobicity caused by the revealed hydrophobic sites from the core of protein.

The liberation and solubilization of proteins from the aleurone layer was also confirmed by the electrophoretic patterns of the protein isolates. The bioprocessing together with cell wall degrading enzymes and phytase (StrEP) showed more intensively stained bands that were identified as gloubulin-3A and $-3 \mathrm{C}$. The globulin $3 \mathrm{~A}$ and $3 \mathrm{C}$ belong to the $7 \mathrm{~S}$ globulin family and has been previously identified in wheat bran and embryo (Chaquilla-Quilca, BalandránQuintana, Huerta-Ocampo, Ramos-Clamont Montfort \& Luna-Valdez, 2018; Loit, Melnyk, MacFarlane, Scott \& Altosaar, 2009). The 7 S globulins in wheat are the major storage protein in aleurone cells but not present in starchy endosperm cells (Khan et al., 2009). The appearing of additional protein bands in the wells of the bioprocessed protein samples were identified as $\beta$-amylase and chitinase. Although, $\beta$-amylases has been found in embryo and endosperm, a recent publication reported $\beta$-amylase also found in the wheat bran layer (Chaquilla-Quilca et al., 2018). In mature grain, only half of the $\beta$-amylase is soluble to water due to forming complexes with other proteins and glutenins (Khan et al., 2009). During bioprocessing of wheat bran these linkages were probably hydrolyzed and thus, increasing the solubility of $\beta$-amylase. Chitinases are fungal growth inhibiting enzymes that hydrolyse the chitin cell walls of fungi and have reported to be found in the intermediate and aleurone layers of wheat bran (Jerkovic et al., 2010; Chaquilla-Quilca et al., 2018).

\subsection{Technofunctional properties of the wheat bran protein isolates}

As expected, all the protein isolates had highest protein solubility at alkaline $\mathrm{pH}$. The results obtained with Control was slightly higher in the $\mathrm{pH}$ range 4-6 than reported by Idris et al. 
(2003), where the minimum protein solubility (20\%) of wheat bran protein was at $\mathrm{pH} 5.5$. Presumably, the lowest protein solubility of the bioprocessed protein isolates were found around the precipitation $\mathrm{pH}$ 5.5. Proteins are electrically neutral ( $\zeta$-potential is zero) at the $\mathrm{pH}$ of their isoelectric point resulting in promoting attractive forces between the proteins leading to aggregation and low solubility (Damodaran, 2008). However, the bioprocessed protein isolates StrE and StrEP showed significantly decreased $\zeta$-potential in pH above 5. The differences in the protein solubility and $\zeta$-potential between the Control and bioprocessed protein isolates was likely due to different protein profiles in the isolates. As shown by the electrophoretic pattern of the isolates, the bioprocessing especially with cell wall hydrolyzing enzymes and phytase caused additional proteins, such as $\beta$-amylase, chitinase and LMW glutenins, to appear in the isolates. The more homogenous protein profile in Control isolate most probably had higher solubility and lower net charge than the more heterogeneous protein profile found in the bioprocessed protein isolates.

The emulsifying and foaming properties of proteins provide information about their potential in food applications. The properties affecting foam and emulsion stability are similar: the protein must be able to adsorb in the air/oil-water interface and partially unfold to expose the hydrophobic areas from the core towards the air/oil phase and hydrophilic areas towards the water phase (Damodaran, 2005). When adsorbed, the protein forms viscous cohesive film that decreases the interfacial tension. An appropriate balance of protein flexibility and rigidity withstands mechanical motion, thus stabilizes the emulsion/foam structure. The emulsions made with the protein emulsions were unstable, showing flocculation and creaming within 30 min after preparation. Even though, the surface hydrophobicity and net charge of the proteins increased in the bioprocessed protein isolates, they were not enough to stabilise the foam structure. If the protein is hydrophilic with little hydrophobic areas at the surface, the protein is not adsorbed at the interface due to the lower free energy at the 
aqueous phase (Damodaran, 2008). Also, if the net charge of the protein is low, the lack of electrostatic repulsion leads to flocculation and coalescence of the oil particles (McClements, 2004). The results obtained were consistent with Wang et al. (1999), where rice bran protein isolate had low emulsifying capacity and stability regardless of the enzyme treatment with xylanase and phytase. They concluded that the low surface hydrophobicity of the enzyme treated rice protein could not stabilise the oil-water-interface. Also, in a study by (Meinlschmidt et al., 2016) the lactic acid fermentation of soy protein isolate decreased the emulsion capacity due to aggregation and crosslinking of partially hydrolyzed proteins. In their work, the fermentation was stopped by a heat treatment that most probably caused also the denaturation and aggregation of the proteins.

Superior foam stability was obtained with the bioprocessed StrE and StrEP compared to the Control. The bioprocessed protein isolates had slower foam height decay and more stable foam structures were formed in comparison to the Control. In addition, the foam half-time was two times higher in StrE and StrEP than in the Control. The higher foaming stability was likely caused by partial hydrolysis and liberation of additional proteins during bioprocessing. The liberated and solubilized proteins were structurally more flexible and prone for unfolding, thus stabilising the foam structure. The increased foaming stability could be also linked to the increased surface hydrophobicity due to the modest hydrolysis of the proteins that exposing the hydrophobic areas from the core of the proteins. Even though, protein surface hydrophobicity has been stated not to have straight-forward correlation with foaming stability, some hydrophobic areas at the surface is needed to anchor the protein at the airwater interface (Damodaran, 2005). Generally, partial protein hydrolysis improves foaming properties as shown by previous studies. Klupsaite et al. (2017) and Meinlschmidt et al (2016) showed that partial hydrolysis of lupine protein and soy protein isolate by lactic acid fermentation increased over two times the foaming capacity and the foam stability was 
maintained when compared to native lupine and soy protein. The authors concluded that the formation of low molecular weight peptides by hydrolysis were more flexible and could transfer rapidly to the air-water interface. This in turn improved the strength of viscoelastic cohesive film by protein-protein linkages and improved the foaming properties by decreasing the surface tension. However, extensive protein hydrolysis caused by treatments with proteolytic enzymes or long fermentation times $(72 \mathrm{~h})$ decreases foam stability (Klupsaite et al., 2017; Jung et al. 2005). Excessive amount of small molecular sized peptides are not able to form viscoelastic films at the interface, thus deteriorating the foam stability.

\section{Conclusions}

In conclusion, the bioprocessing of wheat bran with lactic acid bacteria and cell wall degrading enzymes is an effective tool to modify the chemical and technological properties of the bran proteins. The bioprocessing, especially with addition of enzymes, degraded the starch and cell wall polysaccharides solubilizing proteins from the bran matrix. In addition to the globulin proteins, the bioprocessing liberated and solubilized additional proteins, such as chitinase and $\beta$-amylase from the aleurone layer. Furthermore, the bioprocessing likely hydrolyzed the endosperm proteins attached to the aleurone-side of the bran shown by the amino acid composition, changes in the secondary structures of the protein and appearance of LMW glutenins in the isolates. The bioprocessing had no effect on the emulsifying properties of the proteins. The protein solubility of the bioprocessed protein isolates was significantly lower than of the Control isolate, most probably due to the more heterogeneous protein profile found in the isolates. The emulsifying properties were not improved by bioprocessing. However, the foaming stability was significantly improved when compared to the protein isolate made without bioprocessing.

\section{Acknowledgement}


We thank Outi Brinck, Miikka Olin, Minnamari Edelmann, Juha-Pekka Järvinen and Outi

Nivala for their skillful assistance with the analysis. This work was supported by the Doctoral

School of the University of Helsinki.

\section{Conflict of interest}

The authors state no conflict of interest.

\section{References}

AACC (2003). Approved Methods of the American Association of Cereal Chemists. In Approved Methods of Analysis (11 ${ }^{\text {th }}$ ed.). St. Paul: AACC International. http://methods.aaccnet.org/summaries/44-15-02.aspx

Antoine, C., Peyron, S., Mabille, F., Lapierre, C., Bouchet, B., Abecassis, J., \& Rouau, X. (2003). Individual contribution of grain outer layers and their cell wall structure to the mechanical properties of wheat bran. Journal of agricultural and food chemistry, 51, 2026-2033. https://pubs.acs.org/doi/abs/10.1021/jf0261598

Arte, E., Katina, K., Holopainen-Mantila, U., \& Nordlund, E. (2016). Effect of hydrolyzing enzymes on wheat bran cell wall integrity and protein solubility. Cereal Chemistry Journal, 93, 162-171. https://doi.org/10.1094/CCHEM-03-15-0060-R

Arte, E., Rizzello, C. G., Verni, M., Nordlund, E., Katina, K., \& Coda, R. (2015). Impact of enzymatic and microbial bioprocessing on protein modification and Nutritional properties of Wheat Bran. Journal of agricultural and food chemistry, 63, 8685-8693. https://doi.org/10.1021/acs.jafc.5b03495

Bailey, M. J., Biely, P., \& Poutanen, K. (1992). Interlaboratory testing of methods for assay of xylanase activity. Journal of Biotechnology, 23, 257-270. https://doi.org/10.1016/0168-1656(92)90074-J 
Bao, Y., Boeren, S., \& Ertbjerg, P. (2018). Myofibrillar protein oxidation affects filament charges, aggregation and water-holding. Meat science, 135, 102-108. https://doi.org/10.1016/j.meatsci.2017.09.011

Bilgiçli, N., \& İbanoğlu, Ş. (2007). Effect of wheat germ and wheat bran on the fermentation activity, phytic acid content and colour of tarhana, a wheat flour-yoghurt mixture. Journal of Food Engineering, 78, 681-686. https://doi.org/10.1016/j.jfoodeng.2005.11.012

Bunaciu, A, A., Fleschin, Ş., \& Aboul-Enein, H. (2014). Evaluation of the protein secondary structures using Fourier Transform Infrared Spectroscopy. Gazi University Journal of Science, 21, 637-644. http://dergipark.gov.tr/download/article-file/83624

Chaquilla-Quilca, G., Balandrán-Quintana, R. R., Huerta-Ocampo, J. Á., Ramos-Clamont Montfort, G., \& Luna-Valdez, J. G. (2018). Identification of proteins contained in aqueous extracts of wheat bran through a proteomic approach. Journal of Cereal Science, 80, 31-36. https://doi.org/10.1016/j.jcs.2018.01.005

Church, F. C., Swaisgood, Harold, E., Porter, David, H., \& Catignani, George, L. (1983). Spectrophotometric assay using o-phtaldialdehyde for determination of proteolysis in milk and isolated milk proteins. Journal of Dairy Science, 66, 1219-1227. https://doi.org/10.3168/jds.S0022-0302(83)81926-2

Coda, R., Rizzello, C. G., Curiel, J. A., Poutanen, K., \& Katina, K. (2014). Effect of bioprocessing and particle size on the nutritional properties of wheat bran fractions. Innovative Food Science \& Emerging Technologies, 25, 19-27. https://doi.org/10.1016/j.ifset.2013.11.012

Damodaran, S. (2005). Protein stabilization of emulsions and foams. Journal of Food Science, 70, R54-R66. https://doi.org/10.1111/j.1365-2621.2005.tb07150.x

Damodaran, S. (2008). Amino acids, peptides, and proteins. In S. Damodaran, K. L. Parkin, \& O. R. Fennema (Eds.), Fennema's Food Chemistry (pp. 217-330). Boca Raton: CRC Press. 
Di Lena, G., Patroni, E., \& Quaglia, G. B. (1997). Improving the nutritional value of wheat bran by a white-rot fungus. International Journal of Food Science \& Technology, 32, 513-519. https://doi.org/10.1111/j.1365-2621.1997.tb02125.x

FAO (2003). Food and Nutrition paper 77: Food energy - Methdos of analysis and conversion factors. Rome: Food and Agriculture Organization of the United Nations. http://www.fao.org/uploads/media/FAO_2003_Food_Energy_02.pdf

Fardet, A. (2010). New hypotheses for the health-protective mechanisms of whole-grain cereals: what is beyond fibre? Nutrition research reviews, 23, 65-134. https://doi.org/10.1017/S0954422410000041

Gänzle, M. G. (2014). Enzymatic and bacterial conversions during sourdough fermentation. Food microbiology, 37, 2-10. https://doi.org/10.1016/j.fm.2013.04.007

Gänzle, M. G. \& Gobbetti, M. (2013). Physiology and biochemistry of lactic acid bacteria. In M. Gobbetti, \& M. Gänzle (Eds.), Handbook of Sourdough Biotechnology: Physiology and biochemistry of lactic acid bacteria (pp. 155-182) New York: Springer Science+Business Media.

Idris, W. H., Babiker, E. E., \& El Tinay, A. H. (2003). Fractionation, solubility and functional properties of wheat bran proteins as influenced by $\mathrm{pH}$ and/or salt concentration. Die Nahrung, 47, 425-429. https://doi.org/10.1002/food.200390094

Jensen, S. A., \& Martens, H. (1983). The botanical constituents of wheat and wheat milling fractions. II. Quantification by amino acids. Cereal Chemistry Journal, 60, 280-177. http://www.aaccnet.org/publications/cc/backissues/1983/Documents/chem60_172.pdf

Jerkovic, A., Kriegel, A. M., Bradner, J. R., Atwell, B. J., Roberts, T. H., \& Willows, R. D. (2010). Strategic distribution of protective proteins within bran layers of wheat protects the nutrient-rich endosperm. Plant physiology, 152, 1459-1470. https://doi.org/10.1104/pp.109.149864 
Jung, S., Murphy, P. A., \& Johnson, L. A. (2005). Physicochemical and functional properties of soy protein substrates modified by low levels of protease hydrolysis. Journal of Food Science, 70, C180-C187. https://doi.org/10.1111/j.1365-2621.2005.tb07080.x

Katina, K., Juvonen, R., Laitila, A., Flander, L., Nordlund, E., Kariluoto, S., Piironen, V., \& Poutanen, K. (2012). Fermented wheat bran as a functional Ingredient in baking. Cereal Chemistry Journal, 89, 126-134. https://doi.org/10.1094/CCHEM-08-11-0106

Khan, K., \& Shewry, P. R. (2009), Wheat, chemistry and technology. (4 ${ }^{\text {th }}$ ed.). St. Paul: AACC International, Inc.

Klupsaite, D., Juodeikiene, G., Zadeike, D., Bartkiene, E., Maknickiene, Z., \& Liutkute, G. (2017). The influence of lactic acid fermentation on functional properties of narrow-leaved lupine protein as functional additive for higher value wheat bread. $L W T, 75,180-186$. https://doi.org/10.1016/j.lwt.2016.08.058

Laemmli, U. K. (1970). Cleavage of structural proteins during the assembly of the head of bacteriophage T4. Nature, 227, 680-685. https://doi.org/10.1038/227680a0

Loit, E., Melnyk, C. W., MacFarlane, A. J., Scott, F. W., \& Altosaar, I. (2009). Identification of three wheat globulin genes by screening a Triticum aestivum BAC genomic library with cDNA from a diabetes-associated globulin. BMC Plant Biology, 9, 93. https://doi.org/10.1186/14712229-9-93

Marcone, M. F., Kakuda, Y., \& Yada, R. Y. (1998). Salt-soluble seed globulins of dicotyledonous and monocotyledonous plants II. Structural characterization. Food Chemistry, 63, 265-274. https://doi.org/10.1016/S0308-8146(97)00159-3

McClements, D. J. (2004). Protein-stabilized emulsions. Current Opinion in Colloid \& Interface Science, 9, 305-313. https://doi.org/10.1016/j.cocis.2004.09.003 
Meinlschmidt, P., Ueberham, E., Lehmann, J., Schweiggert-Weisz, U., \& Eisner, P. (2016). Immunoreactivity, sensory and physicochemical properties of fermented soy protein isolate. Food Chemistry, 205, 229-238. https://doi.org/10.1016/j.foodchem.2016.03.016

Meziani, S., Nadaud, I., Gaillard-Martinie, B., Chambon, C., Benali, M., \& Branlard, G. (2012). Proteomic analysis of the mature kernel aleurone layer in common and durum wheat. Journal of Cereal Science, 55, 323-330. https://doi.org/10.1016/j.jcs.2012.01.010

Nordlund, E., Katina, K., Aura, A.-M., \& Poutanen, K. (2013). Changes in bran structure by bioprocessing with enzymes and yeast modifies the in vitro digestibility and fermentability of bran protein and dietary fibre complex. Journal of Cereal Science, 58, 200-208. https://doi.org/10.1016/j.jcs.2013.05.006

Prückler, M., Siebenhandl-Ehn, S., Apprich, S., Höltinger, S., Haas, C., Schmid, E., \& Kneifel, W. (2014). Wheat bran-based biorefinery 1: Composition of wheat bran and strategies of functionalization. $L W T, 56,211-221$. https://doi.org/10.1016/j.lwt.2013.12.004

Regvar, M., Eichert, D., Kaulich, B., Gianoncelli, A., Pongrac, P., Vogel-Mikuš, K., \& Kreft, I. (2011). New insights into globoids of protein storage vacuoles in wheat aleurone using synchrotron soft X-ray microscopy. Journal of Experimental Botany, 62, 3929-3939. https://doi.org/10.1093/jxb/err090

Santala, O., Lehtinen, P., Nordlund, E., Suortti, T., \& Poutanen, K. (2011). Impact of water content on the solubilisation of arabinoxylan during xylanase treatment of wheat bran. Journal of Cereal Science, 54, 187-194. https://doi.org/ 10.1016/j.jcs.2011.02.013

Shewry, P. R., \& Tatham, A. S. (1990). The prolamin storage proteins of cereal seeds: structure and evolution. Biochemical Journal, 267, 1-12. https:/www.ncbi.nlm.nih.gov/pmc/articles/PMC1131235/

Turunen, S. P., Kummu, O., Harila, K., Veneskoski, M., Soliymani, R., Baumann, M., Pussinen, P. J., \& Hörkkö, S. (2012). Recognition of Porphyromonas gingivalis gingipain epitopes by natural 
IgM binding to malondialdehyde modified low-density lipoprotein. PloS one, 7, e34910. https://doi.org/10.1371/journal.pone.0034910

Wang, M., Hettiarachchy, N. S., Qi, M., Burks, W., \& Siebenmorgen, T. (1999). Preparation and functional properties of rice bran protein isolate. Journal of agricultural and food chemistry, 47, 411-416. https://www.ncbi.nlm.nih.gov/pubmed/10563909

Xu, Y., Wang, Y., Coda, R., Säde, E., Tuomainen, P., Tenkanen, M., \& Katina, K. (2017). In situ synthesis of exopolysaccharides by Leuconostoc spp. and Weissella spp. and their rheological impacts in fava bean flour. International journal of food microbiology, 248, 63-71. https://doi.org/ 10.1016/j.ijfoodmicro.2017.02.012

Zurbriggen, B., Bailey, M. J., Penttilä, M. E., Poutanen, K., \& Linko, M. (1990). Pilot scale production of a heterologous Trichoderma reesei cellulase by Saccharomyces cerevisiae. Journal of Biotechnology, 13, 267-278. https://www.ncbi.nlm.nih.gov/pubmed/1366559 


\section{Figure Captions}

Figure 1. Electrophoretic patterns of wheat bran protein isolates. The pointed bands 1-6 in the figure were identified by MALDI-TOF/TOF. Control: without bioprocessing, Str: bioprocessing with starters, StrE: bioprocessing with starters and cell wall degrading enzymes, StrEP: bioprocessing with starters, cell wall degrading enzymes and phytase.

Figure 2. Protein solubility (A) and $\zeta$-potential $(B)$ of the wheat bran protein isolates in $\mathrm{pH} 4$ 8. Control: without bioprocessing, Str: bioprocessing with starters, StrE: bioprocessing with starters and cell wall degrading enzymes, StrEP: bioprocessing with starters, cell wall degrading enzymes and phytase.

Figure 3. The microscopy images (at $100 \times$ magnification) showing flocculation of $5 \%(\mathrm{v} / \mathrm{v})$ oil-in-water emulsions containing $0.2 \%$ wheat bran protein isolate. The bar represents 50 $\mu \mathrm{m}$. Control: without bioprocessing, Str: bioprocessing with starters, StrE: bioprocessing with starters and cell wall degrading enzymes, StrEP: bioprocessing with starters, cell wall degrading enzymes and phytase.

Figure 4. Time dependent total foaming height $(A)$, bubble count $/ \mathrm{mm}^{2}(B)$ and bubble structure (C) of bioprocessed wheat bran protein isolates. In the figures of total foam height and bubble count $/ \mathrm{mm}^{2}$ (A and B), time zero represents the starting point of air conduction into the solution. In figure $\mathrm{C}$, time zero is the time point, when all the air had been conducted to the solution. Control: without bioprocessing, Str: bioprocessing with starters, StrE: bioprocessing with starters and cell wall degrading enzymes, StrEP: bioprocessing with starters, cell wall degrading enzymes and phytase.

Table 1.

The protein, peptide, fat, total starch, soluble pentosans and free sugar contents of the wheat bran protein isolates (Control; without bioprocessing, Str; bioprocessing with 
starters, StrE; bioprocessing with starters and cell wall degrading enzymes, StrEP bioprocessing with starters, cell wall degrading enzymes and phytase).

\begin{tabular}{lllll}
\hline & Control & Str & StrE & StrEP \\
\hline Protein (\%) & $67.0 \pm 4.0$ & $81.0 \pm 1.9$ & $81.7 \pm 1.5$ & $79.9 \pm 0.3$ \\
Peptide (mg/g isolate) & $62.2 \pm 2.6$ & $75.8 \pm 2.1$ & $59.2 \pm 4.0$ & $57.5 \pm 2.3$ \\
Fat (\%) & $11.5 \pm 0.1$ & $14.9 \pm 0.7$ & $16.8 \pm 0.6$ & $22.8 \pm 1.7$ \\
Total starch (\%) & $13.4 \pm 0.0$ & $2.0 \pm 0.1$ & $1.1 \pm 0.1$ & $0.5 \pm 0.0$ \\
Soluble pentosan (\%) & $2.5 \pm 0.1$ & $1.3 \pm 0.1$ & $1.1 \pm 0.1$ & $1.5 \pm 0.1$ \\
Free sugars (\%) & $0.44 \pm 0.0$ & $0.7 \pm 0.0$ & $0.7 \pm 0.0$ & $0.7 \pm 0.0$ \\
\hline
\end{tabular}

Table 2.

Amino acid content ( $\mathrm{g} / 100 \mathrm{~g}$ of protein) and secondary structures (\%) of wheat bran protein isolates (Control: without bioprocessing, Str: bioprocessing with starters, StrE: bioprocessing with starters and cell wall degrading enzymes, StrEP: bioprocessing with starters, cell wall degrading enzymes and phytase).*

\begin{tabular}{lllll}
\hline Amino acid & Control & Str & StrE & StrEP \\
g/100 g of protein & & & & \\
\hline Ala & $3.88 \pm 0.05^{\mathrm{a}}$ & $4.05 \pm 0.23^{\mathrm{a}}$ & $4.22 \pm 0.11^{\mathrm{a}}$ & $4.26 \pm 0.08^{\mathrm{a}}$ \\
Arg & $7.03 \pm 0.22^{\mathrm{a}}$ & $6.93 \pm 0.58^{\mathrm{a}}$ & $7.12 \pm 0.24^{\mathrm{a}}$ & $7.47 \pm 0.32^{\mathrm{a}}$ \\
Asp & $5.19 \pm 0.25^{\mathrm{a}}$ & $5.42 \pm 0.61^{\mathrm{a}}$ & $6.02 \pm 0.30^{\mathrm{a}}$ & $5.92 \pm 0.25^{\mathrm{a}}$ \\
Cys & $0.44 \pm 0.02^{\mathrm{a}}$ & $0.52 \pm 0.03^{\mathrm{ab}}$ & $0.58 \pm 0.01^{\mathrm{b}}$ & $0.52 \pm 0.03^{\mathrm{ab}}$ \\
Glu & $23.76 \pm 0.68^{\mathrm{a}}$ & $23.45 \pm 1.7^{\mathrm{a}}$ & $22.20 \pm 0.70^{\mathrm{a}}$ & $22.56 \pm 1.23^{\mathrm{a}}$ \\
Gly & $5.34 \pm 0.17^{\mathrm{a}}$ & $5.31 \pm 0.34^{\mathrm{a}}$ & $5.26 \pm 0.14^{\mathrm{a}}$ & $5.52 \pm 0.19^{\mathrm{a}}$ \\
His & $2.98 \pm 0.07^{\mathrm{a}}$ & $2.89 \pm 0.31^{\mathrm{a}}$ & $2.79 \pm 0.14^{\mathrm{a}}$ & $2.92 \pm 0.14^{\mathrm{a}}$ \\
Ile & $3.53 \pm 0.13^{\mathrm{a}}$ & $3.52 \pm 0.11^{\mathrm{a}}$ & $3.58 \pm 0.16^{\mathrm{a}}$ & $3.69 \pm 0.8^{\mathrm{a}}$ \\
Leu & $7.28 \pm 0.10^{\mathrm{a}}$ & $7.33 \pm 0.17^{\mathrm{a}}$ & $7.13 \pm 0.17^{\mathrm{a}}$ & $7.07 \pm 0.08^{\mathrm{a}}$ \\
Lys & $3.05 \pm 0.23^{\mathrm{a}}$ & $3.85 \pm 0.64^{\mathrm{a}}$ & $3.31 \pm 0.12^{\mathrm{a}}$ & $3.55 \pm 0.20^{\mathrm{a}}$ \\
Met & $0.62 \pm 0.06^{\mathrm{a}}$ & $0.63 \pm 0.02^{\mathrm{a}}$ & $0.69 \pm 0.02^{\mathrm{a}}$ & $0.66 \pm 0.05^{\mathrm{a}}$ \\
Phe & $6.49 \pm 1.12^{\mathrm{a}}$ & $5.47 \pm 0.52^{\mathrm{a}}$ & $5.54 \pm 0.24^{\mathrm{a}}$ & $5.65 \pm 0.17^{\mathrm{a}}$ \\
Pro & $8.86 \pm 0.21^{\mathrm{a}}$ & $8.34 \pm 0.16^{\mathrm{b}}$ & $7.53 \pm 0.12^{\mathrm{c}}$ & $7.68 \pm 0.16^{\mathrm{c}}$ \\
Ser & $4.93 \pm 0.27^{\mathrm{a}}$ & $4.97 \pm 0.04^{\mathrm{a}}$ & $4.93 \pm 0.08^{\mathrm{a}}$ & $4.95 \pm 0.02^{\mathrm{a}}$ \\
Thr & $3.16 \pm 0.10^{\mathrm{a}}$ & $3.29 \pm 0.05^{\mathrm{ab}}$ & $3.35 \pm 0.04^{\mathrm{ab}}$ & $3.41 \pm 0.04^{\mathrm{b}}$ \\
Trp & $4.75 \pm 0.99^{\mathrm{a}}$ & $4.44 \pm 0.34^{\mathrm{a}}$ & $6.59 \pm 0.20^{\mathrm{b}}$ & $4.71 \pm 0.10^{\mathrm{a}}$ \\
Tyr & $4.49 \pm 0.19^{\mathrm{a}}$ & $4.77 \pm 0.65^{\mathrm{a}}$ & $4.50 \pm 0.20^{\mathrm{a}}$ & $4.71 \pm 0.32^{\mathrm{a}}$ \\
Val & $4.50 \pm 0.06^{\mathrm{a}}$ & $4.56 \pm 0.10^{\mathrm{ab}}$ & $4.69 \pm 0.04^{\mathrm{ab}}$ & $4.76 \pm 0.05^{\mathrm{b}}$ \\
\hline Secondary structure $(\%)$ & & & \\
\hline a-helix & $12.0 \pm 1.8^{\mathrm{a}}$ & $11.2 \pm 0.6^{\mathrm{a}}$ & $12.5 \pm 2.0^{\mathrm{a}}$ & $10.5 \pm 0.9^{\mathrm{a}}$ \\
$\beta$-sheets & $22.0 \pm 0.9^{\mathrm{a}}$ & $31.4 \pm 3.3^{\mathrm{bc}}$ & $35.1 \pm 3.0^{\mathrm{c}}$ & $28.0 \pm 2.6^{\mathrm{b}}$ \\
$\beta$-turns & $59.7 \pm 1.1^{\mathrm{b}}$ & $49.1 \pm 4.1^{\mathrm{a}}$ & $46.5 \pm 3.6^{\mathrm{a}}$ & $55.8 \pm 3.3^{\mathrm{b}}$ \\
random & $6.2 \pm 1.0^{\mathrm{ab}}$ & $8.3 \pm 1.9^{\mathrm{b}}$ & $5.9 \pm 0.4^{\mathrm{a}}$ & $5.7 \pm 0.1^{\mathrm{a}}$ \\
\hline
\end{tabular}

${ }^{*}$ Results with the same letter among the group and row have no statistical differences $p>0.05$ 

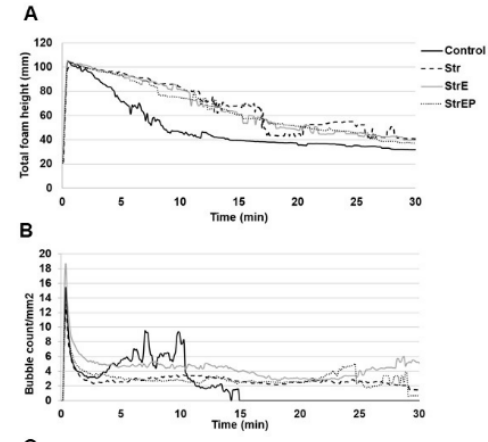

c

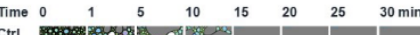

str

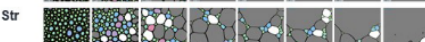

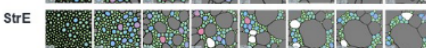

StrEP
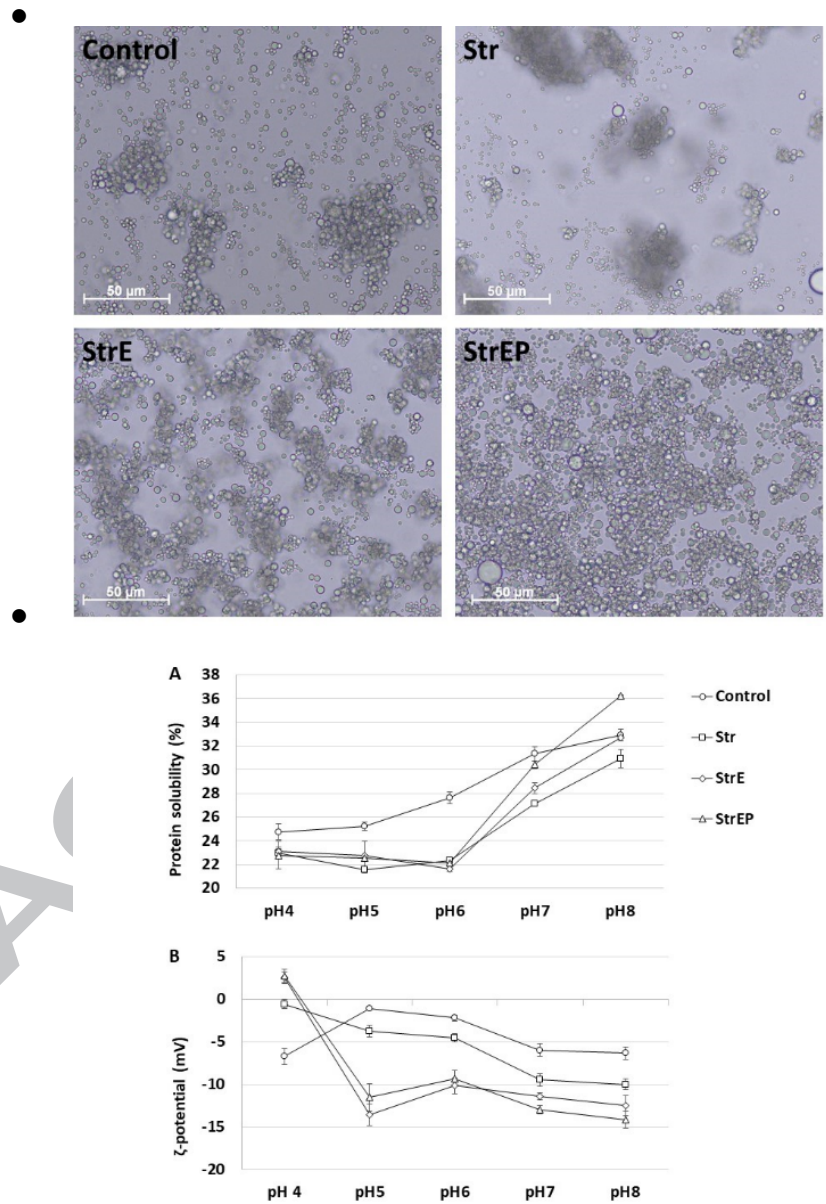


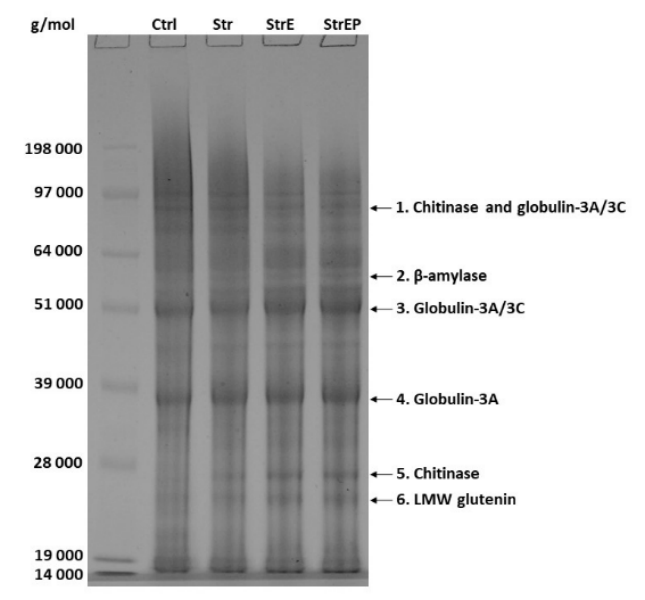

Highlights

- Bioprocessing with hydrolytic enzymes and lactic acid fermentation increased the protein content in the wheat bran protein isolates

- Bioprocessing with hydrolytic enzymes and lactic acid fermentation altered the biochemical properties of the proteins in the isolates

- All bioprocessing methods with lactic acid fermentation with and without hydrolytic enzymes and phytase improved the foaming properties of the bran protein isolate

\section{Declaration of interests}

$\bigotimes$ The authors declare that they have no known competing financial interests or personal relationships that could have appeared to influence the work reported in this paper.

$\square$ The authors declare the following financial interests/personal relationships which may be considered as potential competing interests: 